\title{
Continuous cropping of cut chrysanthemum reduces rhizospheric soil microbial populations, diversity and network complexity
}

Jun Li

Shaoxing University

Xiaoyu Cheng

Shaoxing University

Wei Chen

Shaoxing University

Hanjie Zhang

Shaoxing University

Tianlang Chen

Zhejiang Haifeng Biotechnology Co., LTD

\section{Guixin Chu}

Shaoxing University

Rui Tao ( $\nabla$ taoruisxu@163.com )

Shaoxing University

\section{Research Article}

Keywords: Continuous cropping, cut chrysanthemum, enzyme activity, bacterial community, cooccurrence networks, diversity

Posted Date: November 3rd, 2021

DOI: https://doi.org/10.21203/rs.3.rs-1023064/v1

License: (c) (1) This work is licensed under a Creative Commons Attribution 4.0 International License. Read Full License 


\section{Abstract}

Continuous cropping of cut chrysanthemum causes soil degradation and chrysanthemum quality decline, but the biotic and abiotic mechanisms behind it remain unclear. This impedes our ability to assess the true effects of continuous cropping on agricultural soil functions and our ability to repair impaired soils. Here we examined the impact of different replanting years on microbial communities and enzyme activities in rhizosphere soil of cut chrysanthemum (Chrysanthemum morifolium). Our results showed that soil total nitrogen (TN) and organic carbon (SOC) contents were significantly lower in the soil with 12 years of continuous cropping (Y12) than that in the soil with 1 year of cropping (Y1). Compared with $\mathrm{Y} 1$, Y12 treatment decreased alkaline phosphatase and $\beta$-glucosidase by 12.1 and $24.4 \%$, but increased the activities of soil urease and catalase by 98.2 and $34.8 \%$, respectively. Soil bacterial populations in $Y 6$ (continuous cropping for 6 years) and $\mathrm{Y} 12$ treatments decreased by 52.3 and $87.5 \%$ compared with that in Y1 treatment. Moreover, the bacterial a-diversity (Shannon index) significantly decreased by 37.3 and $57.6 \%$ over 6 and 12 years of continuous cropping, respectively. Long-term monoculture cropping shifted the bacterial community composition, with decreased abundances of dominant phyla such as Proteobacteria and Acidobacteria, but with an increase in the relative abundances of Actinobacteria and Chloroflexi, and Gemmatimonadetes. Moreover, Y 6 and $\mathrm{Y} 12$ treatments harbored less microbial network complexity, lower bacterial taxa, and fewer linkages among bacterial taxa, relative to Y1. Soil pH, SOC, and TN were the main edaphic factors affecting soil bacterial community compositions and diversity. Overall, our results demonstrate that continuous cropping has a significant negative impact on soil microbial diversity and complexity.

\section{Introduction}

Continuous cropping refers to planting a single crop in the same field year after year. This is a vital and common soil management practice in China because of limited arable land resources and lower related agronomic management costs relative to rotation practices [1]. Nevertheless, crop continuous cropping has tremendous pressure on the soil's capacity and negatively affects soil function including serious soil sickness, ecosystem degradation, loss of productivity [2,3]. Thus, it is crucial to find indicators for early evaluation of soil health decline for the sustainable management under continuous cropping system.

Cut chrysanthemum (Chrysanthemum morifolium), which is native to Northeastern Europe and Asia, is the oldest ornamental plant and an important herb and known for a wide range of biodiversity and attractive colors [4]. Cut chrysanthemums are in great demand worldwide and have great export value because of their broad use, such as in tea, medicine, ornaments, and food [5]. China is one of the important exporters of cut chrysanthemums in the world, and the cultivated area is gradually expanding. Continuous cropping of cut chrysanthemum has become the mainstream cultivation practice to obtain higher economic benefits. However, long-term monoculture has negative impacts on soil physical and chemical properties (abiotic factors), thereby threatening chrysanthemum quantity and quality. The soil abiotic characteristics including soil moisture, $\mathrm{pH}$, nutrient, and organic matter (SOM) mediate the alteration of soil microorganisms $[3,6,7]$, which are likely to be sensitive to continuous monoculture. 
However, the abiotic and biotic mechanism and their interactions behind the adverse effects of continuous monoculture remains unclear.

Soil microbes play an extremely vital role in soil elements cycle and ecosystem functions, regulating the response of soil ecosystems to human disturbance $[8,9]$. Healthy soil is the fundamental guarantee for plant growth and food security in agriculture [10]. Given the significance of soil microorganisms for specific soil functions [11], they must be considered when exploring the mechanisms behind the response of agricultural soil systems to continuous cropping cultivation. Increasing numbers of studies have shown that soil enzyme activities and soil microbial composition maintain a certain relationship in response to continuous cropping $[12,13]$. The effects of continuous cropping on soil microbial community have been accessed in crops and vegetables [14, 15, 16]. For example, Ali et al. [16] reported that rhizospheric soil microbial community diversity significantly reduced during the cucumber continuous cropping. Nevertheless, the dynamic successions of microbial communities of facility horticultural plant rhizosphere soil are less understood [4]. To date, it remains unknown how the response of rhizospheric soil microbial community to long-term cut chrysanthemum continuous cropping.

There are two relationships between species in the microbial community, either competition for resources and space [17] or mutualism [18]. Microbial co-occurring network can reveal the relationships between microbial species and explain the assembly of complex microbial communities in various environments such as oceans and sandy land [19]. Network analysis can also reveal why certain groups of microbes appear together consistently, or whether some groups of microbes are more important to keep the network stability in response to environmental disturbances [20]. In addition, the complexity of the network is an important indicator of the stability and the function of the ecosystem [21]. Therefore, an unknown question is how the complexity of soil microorganism, as expressed by network connectivity, changes with continuous cropping.

Here, this study focused on how the abundance, diversity, composition, and network complexity of rhizospheric soil bacteria change in response to cut chrysanthemum continuous cropping. Moreover, we determined whether alterations in bacterial community caused by continuous cropping are linked with soil properties. We hypothesized that continuous cropping would adversely affect soil bacterial abundance, diversity, and network complexity. The diversity and composition of soil bacteria were quantified by using $16 \mathrm{~S}$ rRNA gene amplicon sequencing. The total amounts of bacteria were applied using the dilution-plate method. The objectives of this study were to (1) evaluate the changes of enzymatic activities to continuous cropping; (2) compare the bacterial population, composition, and diversity in different continuous cropping years; and (3) assess the correlations between the bacterial community and soil properties. These results provided a comprehensive understanding of the response of soil microbial community to cut chrysanthemum continuous cropping, and may conducive to improving agricultural strategies by regulating the community function of soil microbiome to reduce the adverse impacts of long-term monoculture. These findings provided a scientific basis for a comprehensive understanding of the effects of chrysanthemum continuous cropping on soil bacterial 
communities, and could conducive to lower continuous cropping obstacles by regulating the soil microflora.

\section{Materials And Methods \\ 2.1 Experimental site}

The experimental field was located in Zhejiang Haifeng Biotechnology Co., Ltd., Shaoxing city, Zhejiang province, China $\left(29^{\circ} 58^{\prime} \mathrm{N}, 120^{\circ} 34^{\prime} \mathrm{E}\right)$ at an altitude of $24 \mathrm{~m}$. This area belongs to a subtropical monsoon climate. The mean annual rainfall is about $1400 \mathrm{~mm}$, and the mean annual temperature is $16.9^{\circ} \mathrm{C}$. The soil type is fluvo-aquic soil. Some soil basic physicochemical properties were as follows: total soil nitrogen (TN) $3.30 \mathrm{~g} \mathrm{~kg}^{-1}$, soil organic matter (SOM) $33.95 \mathrm{~g} \mathrm{~kg}^{-1}$, total soil phosphorus (TP) $0.27 \mathrm{~g} \mathrm{~kg}^{-1}$, total soil potassium (TK) $74.6 \mathrm{~g} \mathrm{~kg}^{-1}$, ammonium $\left(\mathrm{NH}_{4}{ }^{+} \mathrm{N}\right) 0.55 \mathrm{mg} \mathrm{kg}^{-1}$, nitrate $\left(\mathrm{NO}_{3}{ }^{-} \mathrm{N}\right) 22.01 \mathrm{mg} \mathrm{kg}^{-1}$, available P $14.90 \mathrm{mg} \mathrm{kg}^{-1}$, and $\mathrm{pH} 5.14$.

\subsection{Experimental design}

The experimental field contained 12 greenhouse plots of three monoculture years of treatment with four replicates, each $20.0 \times 10.0 \mathrm{~m}$ in size. The greenhouse plots of different treatments were separated by at least $2 \mathrm{~m}$. Three treatments were selected: planting for only 1 year in 2020 (Y1); continuous cropping for 6 years from 2015-2020 (Y6); and continuous cropping for 12 years from 2009-2020 (Y12), respectively. The cut chrysanthemum seeds (Dendranthema morifolium (Ramat.) Tzvel. cv. Golden fan) were planted in March and September every year. Cut chrysanthemum in this area have always adopted the double cropping system pattern. The $\mathrm{N}, \mathrm{P}_{2} \mathrm{O}_{5}$, and $\mathrm{K}_{2} \mathrm{O}$ application rates were 200,200 , and $400 \mathrm{~kg} \mathrm{ha}^{-1}$, respectively, which were split 6 times for application through fertigation during the one growing season. The special water-soluble fertilizer for flowers with $\mathrm{N}$ of $15 \%, \mathrm{P}_{2} \mathrm{O}_{5}$ of $15 \%$, and $\mathrm{K}_{2} \mathrm{O}$ of $30 \%$ was applied in the history of cultivation. Cut chrysanthemum seeds were first sown in the nursery, and then transplanted to the greenhouse plot for growth after growing seedlings. Each greenhouse had 5,000 chrysanthemums planted in 28 rows, and a drip irrigation line was installed between two planted rows. The irrigation amount throughout the chrysanthemum growing season is $4500 \mathrm{~m}^{3} \mathrm{ha}^{-1}$. Cut chrysanthemums were harvested at the maturity stage by hand.

\subsection{Rhizospheric soil samplings and chemical analyses}

Rhizospheric soil were sampled at the maturity stage of chrysanthemum in 2020 . Totally 10 chrysanthemum plants were collected using the "S" pattern in each plot. The 10 plant rhizosphere soils were mixed into a composite sample. The collection method of rhizosphere soil was as follows: the plants were carefully dug out of the ground, and then gently shook the soil attached to the roots and collected, which was the rhizospheric soil. The collected rhizospheric soils were placed in an ice box and transported to the laboratory, part of which was kept in $-80^{\circ} \mathrm{C}$ for molecular analysis, and the other part was dried naturally at room temperature, and the passed through a 100-mesh sieve for chemical analysis. 
Soil mineral $\mathrm{N}\left(\mathrm{NH}_{4}{ }^{+} \mathrm{N}, \mathrm{NO}_{3}{ }^{-} \mathrm{N}\right)$ was determined by the continuous flow injection analyzer (AA3, SEAL, Germany). Soil pH was measured with the soil: water ratio of 1:2.5 using a pH meter. SOC and TN were measured by the TOC/TN analyzer (Analytikjena, Multi N/C 3000). TP was determined by molybdenum blue colorimetry. Available $\mathrm{P}$ was measured by the Spectrophotometer with $0.5 \mathrm{M} \mathrm{NaHCO}_{3}$ extraction. All the methods mentioned above were followed by [22].

\subsection{Measurement of soil enzymatic activity and soil bacterial populations}

Alkaline phosphatase activity was measured following the method of [23]. $\beta$-glucosidase was measured by the method of [24]. Soil catalase was measured using the method of potassium permanganate titration [25]. Soil urease was incubated with urea as substrate for $5 \mathrm{~h}$ at $37^{\circ} \mathrm{C}$, and then measured by spectrophotometry.

Bacterial populations were enumerated by the method of plate culture count with the beef extract peptone medium [26]. Each count was repeated in 4 independent soil dilutions (repetitions), and expressed in the colony forming unit per gram of dry soil weight (CFU g soil $\left.{ }^{-1}\right)$.

\subsection{High throughput sequencing of 16S rRNA genes}

Soil DNA was extracted from $0.3 \mathrm{~g}$ soil by the Powersoil ${ }^{\mathrm{TM}}$ DNA isolation kits (MoBio, San Diego, CA, USA) followed by the instructions. DNA quality and quantity were checked using NanoDrop 2000 (Thermo Scientific, Wilmington, DE, USA). The extracted DNA was stored in a refrigerator at $-20^{\circ} \mathrm{C}$ until use.

The V4-V5 regions of the bacterial 16S rRNA was amplified using the primers 515F and 907R [27]. PCR reactions were performed in triplicate in a $25-\mu \mathrm{L}$ mixture containing $2 \mu \mathrm{L}$ of $10 \times$ Fast Pfu buffer, $0.5 \mu \mathrm{L}$ of each primer $(10 \mu \mathrm{M}), 2 \mu \mathrm{L}$ of $2.5 \mathrm{mM}$ dNTPs, $0.5 \mu \mathrm{L}$ of Fast Pfu polymerase, and $2 \mu \mathrm{L}$ of purified template DNA (10 ng), and $17.5 \mu \mathrm{L}$ PCR-grade water. The PCR reaction conditions were: denaturation at $95^{\circ} \mathrm{C}$ for 4 min, annealing at $95^{\circ} \mathrm{C}$ for $30 \mathrm{sec}, 55^{\circ} \mathrm{C}$ for $30 \mathrm{sec}, 72^{\circ} \mathrm{C}$ for $30 \mathrm{sec}_{\text {, }}$ and extension at $72^{\circ} \mathrm{C}$ for 6 min for 30 cycles. The PCR products were purified and subjected to emulsion PCR, and then sent for Illumina MiSeq sequencing at the Personal Biotechnology Co., Ltd. (Shanghai, China).

Overlapping raw paired-end reads were merged with FLASH (v 1.2.11) [28]. Merged sequences were processed using the QIIME toolkit (v 2018.6) [29]. Chimeric sequences were excluded by using USEARCH. The high-quality sequences were clustered into operational taxonomic units (OTUs) at $97 \%$ sequence identity by the UPARSE [30]. The taxonomic identity of 16S rRNA sequences was performed using BLAST (Basic Local Alignment Search Tool) of NCBI (National Centre for Biotechnology Information).

\subsection{Microbial co-occurrence network construction}

Network analysis was conducted to reveal the bacterial taxa co-occurrence patterns. To decrease the complexity of the datasets, OTUs presenting in more than 3 samples were reserved for the network construction. Similarity matrices were assessed using Spearman rank correlation. The one node in 
networks expressed individual OTU. The edges in the networks represented statistically significant $(P<$ 0.01 ) Spearman correlations with $R^{2}>0.8$. The topological features were estimated by degree, average degree, betweenness, modularity, clustering coefficient, etc. Networks were visualized by the Gephi software [31, 32] by using the Fruchterman-Reingold layout.

\subsection{Statistical Analysis}

The a-diversity (richness and Shannon index) of bacterial community was calculated to evaluate their differences among treatments with different continuous cropping years via the "vegan" package of $R$ software. The relative abundances of bacterial community species were visualized using Circos software online (http://circos.ca/images/). For comparing the difference of bacterial community compositions, $\beta$ diversity was measured via PCA (Principal Component Analysis). Multiple regression model ("stats" package) and variance decomposition analysis ("relaimpo" package in R) were applied to assess the importance of soil chemical properties in explaining the dissimilarities in enzymatic activities and the abundance and diversity of bacterial community. The associations between enzymatic activities and community ( $\alpha$-diversity, $\beta$-diversity, and populations) of soil bacteria were evaluated by Random Forest analysis. The relationships among the top 20 genera of bacteria community in different cropping year treatments were evaluated by the correlation heatmaps in $\mathrm{R}$.

A one-way analysis of variance (ANOVA) was carried out to examine the effect of continuous cropping treatments on the enzymatic activity and abundance and a-diversity (species richness and Shannon index) of bacteria. $P$ value $<0.05$ was defined as statistically significant. These graphs and statistical analyses were performed by the R 3.14 Software.

\section{Results}

\subsection{Soil chemical characteristics}

Continuous cropping treatments significantly affected soil chemical properties (Table S1). Continuous cropping resulted in a nearly 1 unit increase of soil pH after 12 years $(P<0.05)$. The SOC content and total nitrogen were significantly decreased as the age of continuous cropping years increases $(P<0.05)$. By contrast, the total $\mathrm{P}$ and available $\mathrm{P}$ were significantly greater in the $\mathrm{Y} 6$ and $\mathrm{Y} 12$ treatments than in $\mathrm{Y} 1$ treatment $(P<0.05)$. Continuous cropping had negative effects on $\mathrm{NO}_{3}{ }^{-}-\mathrm{N}$ content but had almost no effects on $\mathrm{NH}_{4}{ }^{+}-\mathrm{N}$. Overall, continuous cropping adversely affected most of the soil chemical properties in the cut chrysanthemum field.

\subsection{Soil enzymatic activity}

Soil enzymatic activities of alkaline phosphatase and $\beta$-glucosidase were significantly lower in the continuous cropping treatments (Fig. 1). For example, compared with $\mathrm{Y} 1$ treatment, the activities of these two enzymes were 12.1 and $24.4 \%$ lower in the Y12 treatment, respectively. Furthermore, with increasing cropping years, alkaline phosphatase activity decreased (Fig. 1b). By contrast, soil enzyme activities of 
urease and catalase were significantly higher $(P<0.05)$ in the $Y 12$ treatment than in the Y1 treatment (Fig. 1c, d). Therefore, alkaline phosphatase and $\beta$-glucosidase can be used as indicators of continuous cropping obstacles in cut chrysanthemum soil.

\subsection{Populations and diversity of soil bacteria}

The soil bacterial populations gradually decreased in the soils with continuous cropping of cut chrysanthemum (Fig. 2a). Compared to $\mathrm{Y} 1$ treatment, $\mathrm{Y} 12$ years decreased soil bacterial populations by 87.5\%. The a-diversities of soil bacteria (Shannon index) were significantly lower in $\mathrm{Y} 6$ and $\mathrm{Y} 12$ treatments than in $\mathrm{Y} 1$ treatment (Fig. 2a). Compared with $\mathrm{Y} 1$ and $\mathrm{Y} 6$ treatments, $\mathrm{Y} 12$ treatment decreased Shannon index by 10.44 and $6.49 \%$, respectively. However, the Chao1 index did not change during the 12 years of continuous cropping ( $P>0.05$, Fig. $2 \mathrm{~b}$ ). Overall, continuous cropping resulted in significant decreases in soil bacterial populations and diversity.

The phylum compositions of bacteria in the three treatments are shown in Fig. $2 \mathrm{~d}$. The top five phyla ignificant."statistically were Proteobacteria (34.03\%-41.59\%), Actinobacteria (11.5\%-23.73\%), Chloroflexi (9.95\%-13.67), Acidobacteria (6.58-18.63\%), and Gemmatimonadetes (6.38\%-13.34\%). These five phyla comprised over $88 \%$ of the overall relative abundance. The Proteobacteria was the dominant phylum in all plots, with the percentage highest for $\mathrm{Y} 1$ (41.59\%) and lowest for Y6 (34.03\%). Moreover, continuous cropping treatments had lower Acidobacteria percentages compared to only cropping 1-year. By contrast, continuous cropping led to the significant increase of the relative abundance of Actinobacteria and Chloroflexi, and Gemmatimonadetes.

\section{4 $\beta$-diversity and keystone species identify}

Venn diagram was used to distinguish the difference of bacterial community based on unique and shared OTUs across three treatments (Fig. 3a). A total of 25221 OTUs were observed in Y1, Y6 and Y12 treatments (Fig. 3a), there was 886 shared OTUs (3.5\% of the total). The number of shared OTUs was 2,103 in the group of $Y 1$ and $Y 6$ (8.3\% of the total), while the number of shared OTUs was 1,368 in the group of $\mathrm{Y} 1$ and $\mathrm{Y} 12$, (5.4\% of the total) (Fig. 3a), indicating that the bacterial community changed more significantly after 12 years of continuous cropping than after 6 years of continuous cropping.

PCA analysis showed that the community structure of bacteria was differentiated among different continuous cropping treatments, axis 1 and axis2 explained $43.2 \%$ and $34 \%$ of the total variation (Fig. $3 \mathrm{~b}$ ). Heatmap showed that the community composition of bacteria based on top 20 genus was similar to that in $\mathrm{Y} 6$ and $\mathrm{Y} 12$ and significantly differentiated from that in $\mathrm{Y} 1$ (Fig. 3c). Continuous cropping lowered the genus of Pseudolabrys, Gemmatimonas, Subgroup_6, Haliangium, Devosia, SC-1-84, Bryobacter, Candidatus_Solibacter, and Bradyrhizobium were enriched in AD3, KD4-96, Ellin6067, Sphingomonas, Streptomyces, Luteimonas, Nocardioide. Random forest indicated that the genus of Stenotrophomonas, CL500-29_marine_group, cvE6, Bradyrhizobium, OM27_clade, and Mycobacterium made more contributions to the change of bacterial community composition caused by continuous cropping (Fig. 3d). 


\subsection{The microbial network complexity}

The soil bacterial co-occurrence networks were built under different continuous cropping systems (Fig. 4). The network of the $Y 1$ treatment consisted of 595 nodes linked by 2,352 edges, which were significantly higher than those in $Y 6$ (428 nodes, 1,468 edges) and $Y 12$ treatment (381 nodes, 1,096 edges), suggesting the strong co-occurrence patterns of soil bacteria under the only one-year cropping system. Moreover, according to the topological properties of the networks, the modularity and average degree of the network in the Y12 treatment were the lowest among three treatments, suggesting that continuous cropping leads to the simplification of the bacterial community.

\subsection{The correlations between soil enzymatic activities and bacterial biological traits}

Soil bacterial populations were significantly correlated with catalase $(P=3.4 \mathrm{e}-05$, Fig. $5 \mathrm{c})$ and urease activities $(P=0.0011$, Fig. $5 \mathrm{~d})$, but not with the activities of $\beta$-glucosidase and alkaline phosphatase $(P>$ 0.05 , Fig. $5 \mathrm{a}, \mathrm{b})$. There are significant positive correlations between bacterial community composition and catalase ( $P=1.7 \mathrm{e}-05$, Fig. $5 \mathrm{~g})$ and urease $(P=0.0012$, Fig. $5 \mathrm{~h})$. Soil a-diversity (i.e., Shannon index) significantly and positively correlated with $\beta$ - glucosidase $(P=0.016$, Fig. $5 i)$ and negatively correlated with catalase $(P=6.6 \mathrm{e}-05$, Fig. 5k). These results suggested that the activities of soil $\beta$-glucosidase and catalase were closely linked with the change of bacterial community under a continuous cropping system.

\subsection{The associations between soil chemical properties and soil biological traits}

The relationships among soil properties, bacterial community (populations and diversities), and soil enzymatic activities were shown in Fig. 6. pH, SOC, total $\mathrm{N}$, and available $\mathrm{P}$ were strong soil factors for dissimilarities of the $\beta$-diversity, populations, and Shannon index of bacteria. The selected soil chemical properties had the greatest explanation for the $\beta$-diversity of soil bacteria $(93.62 \%)$, followed by the populations of bacteria (87.40\%). The explanations of selected soil properties for three types of enzymes (i.e., alkaline phosphatase, catalase and $\beta$-glucosidase) were significantly higher than those for urease. a positive correlation between $\mathrm{pH}$ and the, with the importance coefficient of 3.34, and a negative correlation between $\mathrm{pH}$ and the number of bacteria and Shannon index, with the importance coefficient of 2.02 and 1.83 , respectively. $\mathrm{pH}$ was the negative factor that significantly affected $\beta$-diversity of bacteria (importance $=3.34, P=0.0099$ ), whilst positively affected populations (importance $=2.02$ ) and Shannon index of bacteria (importance $=1.83$ ). In addition, SOC and total $\mathrm{N}$ significantly and negatively affected $\beta$ diversity of bacteria, with the importance coefficients of 6.85 and 7.46, respectively, whilst SOC and total $\mathrm{N}$ positively correlated with soil bacterial populations (importance coefficients of 7.23 and 7.56, respectively) and Shannon index (importance coefficients of 7.19 and 6.03, respectively. Interestingly, the effect of soil phosphorus on biological traits were opposite to that of SOC and TN. 


\section{Discussion}

\subsection{Continuous reduces microbial diversity and populations}

Bacterial diversity is a key component of soil biodiversity. Soil biodiversity is positively related to the sustainability of the ecosystem [33], however, which is sensitive to the change in farmland management strategies (e.g., cropping systems, tillage). In this study, a-diversities (Shannon index) of bacterial communities in $\mathrm{Y} 6$ and $\mathrm{Y} 12$ were significantly lower than that in $\mathrm{Y} 1$ treatment. Moreover, rhizosphere soil bacterial a-diversity decreased with the extension of continuous cropping time. A reduced diversity of soil bacteria may result in an incompact ecosystem [34], as such, continuous cropping of cut chrysanthemum destroyed the functional stability of the soil. Our finding was in line with the findings of [3], who stated that the a-diversity of the bacterial community in soybean corn rotation system was higher than that in monocrop continuous cropping treatment. The rhizospheric soil Shannon index was significantly declined over time, possibly because of the accumulation of a large number of pathogenic bacteria in the rhizosphere, thereby generating continuous cropping obstacles. Moreover, the simplification of plant species and root exudates type (e.g., carbohydrates and amino acids) caused by continuous cropping would decrease the diversity of soil microorganism [35]. This viewpoint was also evidenced by [36], who reported that plant roots in monocropping would repeatedly release the same exudates, which may lead to a significant increase in the number of pathogens that use these substrates. However, our result is inconsistent with the finding of [3], Who found that continuously planting soybeans for 13 years led to the increases of soil bacterial diversity and abundance. The possible reason for this difference is that rhizosphere soil and bulk soil respond differently to tillage. Bulk soils in the continuous cropping system may be more susceptible to other agricultural management practices such as fertilization. Schmidt et al. [37] demonstrated that agricultural managements had different effects on root and soil bacterial communities. In our study, the richness (Chao1 index) was not affected by the continuous cropping (Fig. 2b). This is consistent with a previous observation that the richness was less variable in responses

to environmental change than the diversity [38]. Changes in the composition of microbial communities do not necessarily result in changes in richness or diversity, due to the existence of functional redundancy [39].

In the present study, our results showed that continuous cropping of cut chrysanthemum led to a significant reduction in rhizosphere soil bacterial populations. Our finding is consistent with the result of prior study [40], indicating that long term continuous planting of soybean reduced the rhizospheric soil bacterial counts. In a previous study, long-term continuous cropping caused microflora changing from "bacterial-type" to "fungal-type", and bacterial abundance showed a downward trend [41]. Similarly, with the increase of the consecutive monoculture years, the total amount of soil bacteria in the sweet potato field decreased significantly [42].

Variations in the microbial composition may affect the microbial function [43]. We observed that rhizosphere soil bacterial community of cut chrysanthemum was obviously distinct among different cropping years (Fig. 2d; Fig. 3b). Our finding was similar to the results from the Lanzhou lily continuous 
cropping system, where the microbial community compositions were distinguished into three groups during 9 years of continuously replanting [44]: one group ( $0-3$ years), second group ( $3-6$ years), and third group (6-9 years). In addition, a similar result was gained in the monoculture system of soybean [3].

\subsection{Changes of relative abundance of potentially pathogenic bacterial groups}

At the phylum level, the top one phylum Proteobacteria were significantly decreased by the continuous cropping (Fig. 2d). Proteobacteria have been widely reported as the predominant bacterial phyla in rhizospheric soils because of their rapid growth rates [45]. The phylum Proteobacteria includes plentiful beneficial taxa such as plant growth-promoting bacteria, which promote nutrient absorption and prevent diseases, and are closely related to plant disease [46]. A prior study has reported that the antagonistic role of Proteobacteria in the plant rhizosphere was diminished during continuous cropping [15]. Our results supported these views that the relative of abundance Proteobacteria was suppressed over chrysanthemum monoculture cropping.

Another beneficial predominant phylum Acidobacteria (the fourth abundant, average relative abundance $=11.17 \%$ ) was significantly lower in $\mathrm{Y} 6$ and $\mathrm{Y} 12$ treatments than that in $\mathrm{Y} 1$ treatment. Our result is in agreement with the finding of Yin et al. [47], who demonstrated that lower frequencies in the rhizosphere of diseased plants were found than in healthy plants. In contrast, the phylum Actinobacteria was significantly elevated in the soils of $Y 6$ and $Y 12$ treatments relative to that of $Y 1$. This may be due to the increased nutrient availability of soil over many years of fertilization during chrysanthemum continuous cropping leading to an increase in this copiotrophic bacteria [41]. Gemmatimonadetes are known to conduce to SOC sequestration and decomposition of cellulose and lignin [48]. The relative abundance of the Gemmatimonadetes was reported to be closely linked with soil nutrients [48]. In the present research, the relative abundance of Gemmatimonadetes was higher in the rhizospheric soils of $\mathrm{Y} 6$ and $\mathrm{Y} 12$ treatments than that in $\mathrm{Y} 1$ treatment, as higher nutrients contents (e.g. $\mathrm{AP}_{1} \mathrm{NO}_{3}{ }^{-}$) were detected in the $\mathrm{Y} 12$ treatment (Table 1), which supported above viewpoint very well.

Table 1

Changes of soil physical and chemical properties under long-term continuous cropping system

\begin{tabular}{|c|c|c|c|c|c|c|c|}
\hline Treatment & $\mathrm{pH}$ & $\begin{array}{l}\text { Total N/ } \\
\left(\mathrm{g} \mathrm{kg}^{-1}\right)\end{array}$ & $\begin{array}{l}\mathrm{sOC} / \\
\left(\mathrm{g} \mathrm{kg}^{-1}\right)\end{array}$ & $\begin{array}{l}\text { Total P/ } \\
\left(\mathrm{g} \mathrm{kg}^{-1}\right)\end{array}$ & $\begin{array}{l}\text { Avail P/ } \\
\left(\mathrm{mg} \mathrm{kg}^{-1}\right)\end{array}$ & $\begin{array}{l}\mathrm{NH}_{4}^{+}-\mathrm{N} / \\
\left(\mathrm{mg} \mathrm{kg}^{-1}\right)\end{array}$ & $\begin{array}{l}\mathrm{NO}_{3}{ }^{-}-\mathrm{N} / \\
\left(\mathrm{mg} \mathrm{kg}^{-1}\right)\end{array}$ \\
\hline Y1 & $5.14 b$ & $3.30 \mathrm{a}$ & $33.95 \mathrm{a}$ & $0.27 \mathrm{~b}$ & $12.37 b$ & $5.5 a$ & 199 b \\
\hline Y6 & $5.18 b$ & $2.59 \mathrm{~b}$ & $25.22 b$ & $0.34 \mathrm{a}$ & $28.49 a$ & $4.5 \mathrm{a}$ & $149 \mathrm{~b}$ \\
\hline Y12 & $6.11 \mathrm{a}$ & $2.35 \mathrm{c}$ & $22.50 \mathrm{~b}$ & $0.34 \mathrm{a}$ & $29.80 \mathrm{a}$ & $5.8 \mathrm{a}$ & $111 \mathrm{a}$ \\
\hline
\end{tabular}


At the genus level, the genera Stenotrophomonas, CL500-29_marine_group, cvE6, and Bradyrhizobium played important roles in inducing the changes of community compositions under this continuous cropping system (Fig. 3d). In another continuous cropping system (Panax notoginseng), the genus Stenotrophomonas has been identified to be a key bacterial pathogen that led to the incidence of soilborne disease under Panax notoginseng monoculture system [49]. The second important species, CL50029_marine_group (belong to Acidimicrobiaceae), has been shown to play a dominant role in the carbon and nitrogen cycle [50]. Moreover, CL500-29_marine_groups were often considered as predominant groups in freshwater [51]. In the present study, the higher abundances of the CL500-29_marine_group were detected in continuous cropping treatments with low contents of TN and SOC, suggesting that this genus exhibits high energy metabolism in $\mathrm{C} / \mathrm{N}$-limited soil conditions not only in freshwater conditions. The third important species, cvE6 belonging to chlamydial, was first detected in freshwater samples and named in 2001 [52]. All the chlamydiae described until now are able to infect vertebrates and induce diseases of the living body, but the target of infection is mainly vertebrates, including humans. Our study is the first-time report that the genus $C V E 6$ may be a potential cause of plant disease in the soil subject to continuous cropping obstacle. Furthermore, the relative abundance of Bradyrhizobium decreased over continuous cropping years, and a similar finding was also reported by Xiong et al. [53] in which the amount of the Bradyrhizobium reduced over the years of vanilla continuous cropping. Numerus studies have demonstrated that Bradyrhizobium played crucial roles in plant growth [54] and the suppression of soil-borne diseases [55], suggesting that the reduction of beneficial bacterial taxa may be the reason for the outbreak of soil diseases after 12-year continuous cropping of chrysanthemums.

\subsection{Changes in microbial communities induced by soil factors under continuous cropping}

Continuous cropping can cause changes in edaphic factors thereby affecting soil microbial community compositions and diversity. Our results showed that soil factors were significantly changed after 12 years of continuous cropping (Table 1). In this study, the results of soil SOC and TN were significantly lower in continuous cropping treatments than that in a one-year cropping system, which is in line with prior report [53]. Similarly, monocrop continuous cropping resulted in the unbalance of soil nutrients and the deterioration of soil properties [56]. On the contrary, the available nutrient $\left(\mathrm{AP}\right.$ and $\mathrm{NO}_{3}{ }^{-}$) and $\mathrm{pH}$ increased with continuous cropping years, which is in agreement with the findings of Zhong et al. [57], who demonstrated that long-term continuously cropped banana significantly increased soil available nutrients and soil pH value. In our study, $\mathrm{pH}$ exhibited the greatest effects on the composition and diversity of soil bacteria during continuous cropping of cut chrysanthemum even the $\mathrm{pH}$ varied $<1.0$ units across different treatments (Table 1; Fig. 6). This finding is consistent with those of Degrune et al. [58], who reported that bacterial growth was significantly affected even soil $\mathrm{pH}$ varied $<0.5$ units. Potentially, most bacterial groups exhibit a relatively narrow $\mathrm{pH}$ tolerance threshold [7].

Organic carbon is tightly asociated with changes in microbial communities under continuous cropping system. Soil organic carbon significantly decreased with the years of cut chrysanthemum continuous cropping (Table 1), suggesting that the cut chrysanthemum continuous cropping field could be regarded 
as a carbon-deficient system, thereby oligotrophic microorganisms were dominant in mono-cropped chrysanthemum soils, presumably because continuous intensive cultivation broke the soil structure of plow layer and in turn accelerated carbon degradation. Davis et al. [59] reported that SOC was associated with reduced disease incidence.

Soil microbes play an important role in soil P transformation [60]. In our study, Random Forest analysis revealed that AP and TP are important factors affecting the bacterial community and enzyme activity. Research by Shen et al. [61] also indicated that soil available P was relative to Fusarium wilt disease incidence of banana in soil. In addition, TN was the key factor explaining the decrease in populations and diversity of bacterial community in the rhizosphere during continuous cropping (Table 1). This is in line with a previous report that available $\mathrm{N}$ was the main edaphic factor influencing the distribution of the bacterial communities in crop continuous cropping system [62].

\subsection{Continuous cropping reduces the microbial network complexity}

Numerous researches employing microbial co-occurrence network analyses have expanded our understanding of microbial symbiosis patterns in different terrestrial ecosystems [63,64], nevertheless, relatively little is known about the relationship between the patterns of microbial networks and soil function under continuous cropping system. The numbers of edges and nodes for the bacterial communities in $\mathrm{Y} 6$ and $\mathrm{Y} 12$ treatments were remarkably lower than those in the $\mathrm{Y} 1$ treatment, which indicated that $Y 6$ and $Y 12$ had smaller network sizes and lower taxa involved in the microbial interactions than that in $\mathrm{Y} 1$ treatment, suggesting that long-term continuous cropping of cut chrysanthemum led to the relatively simplified bacterial community. In general, microbial communities with greater network modularity are considered as better organized communities, which may lead to a more stable ecosystem. In the present study, the numbers of network modularity were significantly lower in Y 6 and $\mathrm{Y} 12$ treatments than that in the $\mathrm{Y} 1$ treatment, indicating that the occurrence of continuous cropping obstacle may be due to the reduction of specific functional taxa and loose network structures caused by low modularity. Moreover, since complex soil microbial communities are more resistant and/or resilient to environmental disturbances [65] than simple individuals, a reduction in diversity and network complexity of soil microorganisms due to continuous cropping may have permanent negative effects on soil functions. As Morriën et al. [66] reported that soil microbial networks become tighter and absorb more carbon as nature restoration progresses, thus, when repairing the soil with continuous cropping obstacles, we should pay more attention to the improvement of physicochemical properties (e.g., SOC), and thereby effectively increase the complexity of soil microorganisms.

\section{Conclusions}

In summary, continuous cropping significantly decreased the enzymatic activities of $\beta$-glucosidase together with alkaline phosphatase, but remarkably increased urease and catalase. Soil bacterial population and diversity (Shannon index) significantly decreased over the years of continuous cropping. 
The bacterial community compositions altered significantly through different replanting years, with the decrease of phylum Proteobacteria and Acidobacteria and the increase of Actinobacteria and Gemmatimonadetes. In particular, the accumulation of the pathogenic bacterial genera of Stenotrophomonas and cVE6 and the depletion of beneficial bacterial genera CL500-29_marine_group and Bradyrhizobium were the reason for the chrysanthemum continuous cropping obstacle under the 12year replanting system. Co-occurrence network analyses indicated that long-term monoculture cropping induced a decrease in microbial complexity and stability. Linear regression equation showed that $\beta$ glucosidase and catalase activities were significantly correlated with the composition and diversity of rhizospheric soil bacterial community, suggesting that $\beta$-glucosidase activity and catalase could be regarded as bio-indicator enzymes in the continuous cropping obstacle soil. Random forest analysis showed that $\mathrm{pH}, \mathrm{SOC}, \mathrm{TN}$, and soil $\mathrm{P}$ availability played crucial roles in inducing the changes of soil enzymes and bacterial community diversity and populations. Overall, our study strongly supports our hypothesis that the soil decline of bacterial community complexity may be a key reason of soil continuous cropping obstacle occurrence after 12-year cut chrysanthemum monoculture.

\section{Declarations}

\section{Data Availability}

The data supporting the findings of this study are available from the corresponding author, Rui Tao, upon request.

\section{Funding}

This work was financially supported by the Basic Public Welfare Research Project of Zhejiang Province (LGN20C150003), P. R. China.

\section{Conflict of Interest}

The authors declare that there is no conflict of interest.

\section{References}

1. Liu J, Yao Q, Li Y, Zhang W, Wang G (2019) Continuous cropping of soybean alters the bulk and rhizospheric soil fungal communities in a Mollisol of Northeast PR China. Land Degrad Dev 30: 1725-1738. https://doi.org/10.1002/ldr.3378

2. Shen Z, Penton CR, Lv N, Xue C, Yuan X, Ruan Y, Li R, Shen Q (2017) Banana Fusarium wilt disease incidence is influenced by shifts of soil microbial communities under different monoculture spans. Microb Ecol 75: 739-750. https://doi.org/10.1007/s00248-017-1052-5

3. Liu Z, Liu J, Yu Z, Yao Q, Li Y, Liang A, Zhang W, Mi G, Jin J, Liu X, Wang G (2020) Long-term continuous cropping of soybean is comparable to crop rotation in mediating microbial abundance, 
diversity and community composition. Soil Till Res 197 :

104503. https://doi.org/10.1016/j.still.2019.104503

4. Li P, Chen J, Li Y, Zhang K, Wang H (2017) Possible mechanisms of control of Fusarium wilt of cut chrysanthemum by Phanerochaete chrysosporium in continuous cropping fields: A case study. Sci Rep 7: 1-13. https://doi.org/10.1038/s41598-017-16125-7

5. Shibata M (2008) Importance of genetic transformation in ornamental plant breeding. Plant Biotechnol 25: 3-8. https://doi.org/10.5511/plantbiotechnology.25.3

6. Tan G, Liu Y, Peng S, Yin H, Zhou Z (2021) Soil potentials to resist continuous cropping obstacle: three field cases. Environ Res 111319. https://doi.org/10.1016/j.envres.2021.111319

7. Rousk J, Bååth E, Brookes PC, Lauber CL, Lozupone C, Caporaso JG, Knight R, Fierer N (2010) Soil bacterial and fungal communities across a pH gradient in an arable soil. ISME J 4: 13401351. https://doi.org/10.1038/ismej.2010.58

8. Delgado-Baquerizo M, Maestre FT, Reich PB, Jeffries TC, Gaitan JJ, Encinar D, Berdugo M, Campbell CD, Singh BK (2016) Microbial diversity drives multifunctionality in terrestrial ecosystems. Nat Commun 7: 1-8. https://doi.org/10.1038/ncomms10541.

9. Crowther TW, Hoogen J, Wan J, Mayes MA, Keiser AD, Mo L, Averill C, Maynard DS (2019) The global soil community and its influence on biogeochemistry. Science 365: eaav0550.

https://doi.org/10.1126/science.aav0550

10. Wall DH, Nielsen UN, Six J (2015) Soil biodiversity and human health. Nature 528: 6976. https://doi.org/10.1038/nature15744

11. Zheng Q, Hu Y, Zhang S, Noll L, Wanek W (2019) Soil multifunctionality is affected by the soil environment and by microbial community composition and diversity. Soil Biol Biochem 136: 107521. https://doi.org/10.1016/j.soilbio.2019.107521

12. Li Y, Li Z, Arafat Y, Lin W (2020) Studies on fungal communities and functional guilds shift in tea continuous cropping soils by high-throughput sequencing. Ann Microbiol 70: 1-

12. https://doi.org/10.1186/s13213-020-01555-y

13. Fugen DOU, Wright AL, Mylavarapu RS, Jiang X, Matocha JE (2016) Soil enzyme activities and organic matter composition affected by 26 years of continuous cropping. Pedosphere 26: 618625. https://doi.org/10.1016/S1002-0160(15)60070-4

14. Cha JY, Han S, Hong HJ, Cho H, Kwak YS (2016) Microbial and biochemical basis of a Fusarium wiltsuppressive soil. ISME J 10: 119-129. https://doi.org/10.1038/ismej.2015.95

15. Wei Z, Yu D (2018) Analysis of the succession of structure of the bacteria community in soil from long-term continuous cotton cropping in Xinjiang using high-throughput sequencing. Arch Microbiol 200: 653-662. https://doi.org/10.1007/s00203-018-1476-4

16. Ali A, Ghani MI, Elrys AS, Ding H, Iqbal M, Cheng Z, Cai Z (2021) Different cropping systems regulate the metabolic capabilities and potential ecological functions altered by soil microbiome structure in the plastic shed mono-cropped cucumber rhizosphere. Agr Ecosyst Environ 318: 107486. https://doi.org/10.1016/j.agee.2021.107486

Page 14/24 
17. Hibbing ME, Fuqua C, Parsek MR, Peterson SB (2010) Bacterial competition: surviving and thriving in the microbial jungle. Nat Rev Microbiol 8: 15-25. https://doi.org/10.1038/nrmicro2259

18. Faust K, Raes J (2012) Microbial interactions: from networks to models. Nat Rev Microbiol 10: 538550. https://doi.org/10.1038/nrmicro2832

19. Ma B, Wang H, Dsouza M, Lou J, Xu J (2015) Geographic patterns of co-occurrence network topological features for soil microbiota at continental scale in eastern China. ISME J 10: 1891. https://doi.org/10.1038/ismej.2015.261

20. Fuhrman JA (2009) Microbial community structure and its functional implications. Nature 459: 193199. https://doi.org/10.1038/nature08058

21. Wagg C, Schlaeppi K, Banerjee S, Kuramae EE, Heijden M (2019) Fungal-bacterial diversity and microbiome complexity predict ecosystem functioning. Nat Commun 10: 4841. https://doi.org/10.1038/s41467-019-12798-y

22. Bao SD (2000) Soil Agricultural Chemical Analysis, third ed. Agriculture Press, Beijing. (in Chinese)

23. Wu QS, Zou YN, He XH (2011) Differences of hyphal and soil phosphatase activities in droughtstressed mycorrhizal trifoliate orange (Poncirus trifoliata) seedlings. Sci Hortic 129: 294-298. https://doi.org/10.1016/j.scienta.2011.03.051

24. Eivazi F, Tabatabai MA (1988) Glucosidases and galactosidases in soils. Soil Biol Biochem 20: 601606. https://doi.org/10.1016/0038-0717(88)90141-1

25. Stepniewska Z, Wolinska A, Ziomek J (2009) Response of soil catalase activity to chromium contamination. J Environ Sci 21: 1142-1147. https://doi.org/10.1016/S1001-0742(08)62394-3

26. Pankhurst C, Kirkby C, Hawke B, Harch B (2002) Impact of a change in tillage and crop residue management practice on soil chemical and microbiological properties in a cereal-producing red duplex soil in NSW, Australia. Biol Fert Soils 35: 189-196. https://doi.org/10.1007/s00374-002-04593

27. Zhou J, Wu L, Deng Y, Zhi, X, Jiang YH, Tu Q, Xie J, Nostrand JV, He Z, Yang Y (2011) Reproducibility and quantitation of amplicon sequencing-based detection. ISME J 5: 1303-

1313. https://doi.org/10.1038/ismej.2011.11

28. Magoč T, Salzberg SL (2011) FLASH: fast length adjustment of short reads to improve genome assemblies. Bioinformatics 27: 2957-2963. https://doi.org/10.1093/bioinformatics/btr507

29. Caporaso JG, Kuczynski J, Stombaugh J, Bittinger K, Bushman FD, Costello EK, ... Knight R (2010) QIIME allows analysis of high-throughput community sequencing data. Nat Methods 7: 335-336. https://doi.org/10.1038/nmeth.f.303

30. Edgar RC (2013) UPARSE: highly accurate OTU sequences from microbial amplicon reads. Nat Methods 10: 996. https://doi.org/10.1038/nmeth.2604

31. Newman M (2006) Modularity and community structure in networks. P Natl Acad Sci USA 103: 85778582. https://doi.org/10.1073/pnas.0601602103 
32. Bastian M, Heymann S, Jacomy M (2009, March) Gephi: an open source software for exploring and manipulating networks. In Third international AAAI conference on weblogs and social media

33. Hartman K, Van D, Wittwer RA, Banerj Ee S, Walser JC, Schlaeppi K (2018) Cropping practices manipulate abundance patterns of root and soil microbiome members paving the way to smart farming. Microbiome 6: 14. https://doi.org/10.1186/s40168-017-0389-9

34. Chaer G, Fernandes M, Myrold D, Bottomley P (2009) Comparative resistance and resilience of soil microbial communities and enzyme activities in adjacent native forest and agricultural soils. Microb Ecol 58: 414-424. https://doi.org/10.1007/s00248-009-9508-x

35. Venter ZS, Jacobs K, Hawkins HJ (2016) The impact of crop rotation on soil microbial diversity: A meta-analysis. Pedobiologia 59: 215-223. https://doi.org/10.1016/j.pedobi.2016.04.001

36. Brimecombe MJ, Leij FA, Lynch JM (2001) Nematode community structure as a sensitive indicator of microbial perturbations induced by a genetically modified Pseudomonas fluorescens strain. Biol Fert Soils 34: 270-275. https://doi.org/10.1007/s003740100412

37. Schmidt JE, Kent AD, Brisson VL, Gaudin A (2019) Agricultural management and plant selection interactively affect rhizosphere microbial community structure and nitrogen cycling. Microbiome 7: 118. https://doi.org/10.1007/s003740100412

38. Brown JH, Ernest SM, Parody JM, Haskell JP (2001) Regulation of diversity: maintenance of species richness in changing environments. Oecologia 126: 321-332. https://doi.org/10.1007 /s004420000536

39. Hartmann M, Widmer F (2007) Community structure analyses are more sensitive to differences in soil bacterial communities than anonymous diversity indices. Appl Environ Microb 72: 78047812. https://doi.org/10.1128/AEM.01464-06

40. Zhang Y, Zheng Y, Xia P, Xun L, Liang Z (2019) Impact of continuous Panax notoginseng plantation on soil microbial and biochemical properties. Sci Rep 9: 1-8. https://doi.org/10.1038/s41598-01949625-9

41. Li XG, Ding CF, Hua K, Zhang TL, Zhang YN, Zhao L, Yang Y, Liu J, Wang XX (2014) Soil sickness of peanuts is attributable to modifications in soil microbes induced by peanut root exudates rather than to direct allelopathy. Soil Biol Biochem 78: 149-159. https://doi.org/10.1016/j.soilbio.2014.07.019

42. Gao Z, Hu Y, Han M, Xu J, Wang X, Liu L, Tang Z, Jiao W, Jin R, Liu M, Guan Z, Ma Z (2021) Effects of continuous cropping of sweet potatoes on the bacterial community structure in rhizospheric soil. BMC Microbiol 21: 1-13. https://doi.org/10.1186/s12866-021-02120-6

43. Duffy JE, Cardinale BJ, France KE, Mcintyre PB, Thébault E, Loreau M (2010) The functional role of biodiversity in ecosystems: incorporating trophic complexity. Ecol Lett 10: 522-538. https://doi.org/10.1111/j.1461-0248.2007.01037.x

44. Shi G, Sun H, Calderón:Rrea A, Li M, Su G (2021) Bacterial communities as indicators for soil health under continuous cropping system. Land Degrad Dev 32: 2393-

2408. https://doi.org/10.1002/ldr.3919 
45. Deangelis KM, Brodie EL, Desantis TZ, Andersen GL, Firestone MK (2009) Selective progressive response of soil microbial community to wild oat roots. ISME J 3: 168-178.

https://doi.org/10.1038/ismej.2008.103

46. She S, Niu J, Zhang C, Xiao Y, Chen W, Dai L, Liu X, Yin H. (2017) Significant relationship between soil bacterial community structure and incidence of bacterial wilt disease under continuous cropping system. Arch. Microbiol 199: 267-275. https://doi.org/10.1007/s00203-016-1301-x

47. Yin C, Hulbert SH, Schroeder KL, Mavrodi O, Mavrodi D, Dhingra A, Schillinger WF, Paulitz TC (2013) Role of bacterial communities in the natural suppression of rhizoctonia solani bare patch disease of wheat (Triticum aestivum L.). Appl Environ Microb 79: 7428-7438. https://doi.org/10.1128/AEM.01610-13

48. Xu L, Han Y, Yi M, Yi H, Guo E, Zhang A (2018) Shift of millet rhizosphere bacterial community during the maturation of parent soil revealed by $16 \mathrm{~S}$ rDNA high-throughput sequencing. Appl Soil Ecol 135: 157-165. https://doi.org/10.1016/j.apsoil.2018.12.004

49. Tan Y, Cui Y, Li H, Kuang A, Li X, Wei Y, Ji X (2017) Diversity and composition of rhizospheric soil and root endogenous bacteria in Panax notoginseng during continuous cropping practices. J Basic Microb 57: 337. https://doi.org/10.1002/jobm.201600464

50. Zhang L, Zhong M, Li X, Lu W, Li J (2020) River bacterial community structure and co-occurrence patterns under the influence of different domestic sewage types. J Environ Manage 266: 110590. https://doi.org/10.1016/j.jenvman.2020.110590

51. Hugoni M, Vellet A, Debroas D (2017) Unique and highly variable bacterial communities inhabiting the surface microlayer of an oligotrophic lake. Aquat Microb Ecol 79: 115-125. https://doi.org/10.3354/ame01825

52. Corsaro D, Venditti D, Le Faou A, Guglielmetti P, Valassina M (2001) A new chlamydia-like 16S rDNA sequence from a clinical sample. Microbiology 147: 515-516

53. Xiong W, Zhao Q, Zhao J, Xun W, Li R, Zhang R, Wu H, Shen Q (2015) Different continuous cropping spans significantly affect microbial community membership and structure in a vanilla-grown soil as revealed by deep pyrosequencing. Microb Ecol 70: 209-218. https://doi.org/10.1007/s00248-0140516-0

54. Jayasekhar M, Manonmani K, Justin C (2008) Development of integrated biocontrol strategy for the management of stem rot disease (Fusarium oxysporum $f$. sp. Vanillae) of Vanilla. Agricul Sci Digest 28: $109-111$

55. Aontoun H, Beauchamp CJ, Goussard N, Chabot R, Lalande R (1998) Potential of Rhizobium and Bradyrhizobium species as plant growth promoting rhizobacteria on non-legumes: Effect on radishes (Raphanus sativus L.). Plant Soil 204: 57-67. https://doi.org/10.1007/978-94-017-2321-3_5

56. Chen S, Qi G, Luo T, Zhang H, Jiang Q, Wang R, Zhao X (2018) Continuous-cropping tobacco caused variance of chemical properties and structure of bacterial network in soils. Land Degrad Dev 29: 4106-4120. https://doi.org/10.1002/ldr.3167 
57. Zhong S, Mo Y, Guo G, Zeng H, Jin Z (2014) Effect of continuous cropping on soil chemical properties and crop yield in banana plantation. J Agr Sci Tech 16: 239-250

58. Degrune F, Dufrêne M, Colinet G, Massart S, Taminiau B, Bodson B, Hiel MP, Daube G, Nezer C, Vandenbol M (2015) A novel sub-phylum method discriminates better the impact of crop management on soil microbial community. Agron Sustain Dev 35: 1157-

1166. https://doi.org/10.1007/s13593-015-0291-4

59. Davis JR, Huisman OC, Everson DO, Schneider AT (2001) Verticillium wilt of potato: a model of key factors related to disease severity and tuber yield in Southeastern Idaho. Am J Potato Res 78: 291300. https://doi.org/10.1007/BF02875694

60. Stewart JWB, Tiessen H (1987) Dynamics of soil organic phosphorus. Biogeochemistry 4: 41-60. https://doi.org/10.1007/BF02187361

61. Shen Z, Ruan Y, Xue C, Zhong S, Li R, Shen Q (2015) Soils naturally suppressive to banana Fusarium wilt disease harbor unique bacterial communities. Plant Soil 393: 21-33.

https://doi.org/10.1007/s11104-015-2474-9

62. Li JG, Shen MC, Hou JF, Li L, Wu JX, Dong YH (2016) Effect of different levels of nitrogen on rhizosphere bacterial community structure in intensive monoculture of greenhouse lettuce. Sci Rep 6: 1-9. https://doi.org/10.1038/srep25305

63. de Vries FT, Griffiths RI, Bailey M, Craig H, Girlanda M, Gweon HS... Bardgett RD (2018) Soil bacterial networks are less stable under drought than fungal networks. Nat Commun 9: 3033. https://doi.org/10.1038/s41467-018-05516-7

64. Banerjee S, Walder F, Büchi L, Meyer M, Held AY, Gattinger A, Keller T, Charles R, van der Heijden MG (2019) Agricultural intensification reduces microbial network complexity and the abundance of keystone taxa in roots. ISME J 13: 1722-1736. https://doi.org/10.1038/s41396-019-0383-2

65. Allison SD, Martiny J (2008) Resistance, resilience, and redundancy in microbial communities. P Natl Acad Sci USA 105: 11512-11519. https://doi.org/10.1073/pnas.0801925105

66. Morriën E (2016) Understanding soil food web dynamics, how close do we get? Soil Biol Biochem 102: 10-13. https://doi.org/10.1016/j.soilbio.2016.06.022

\section{Figures}



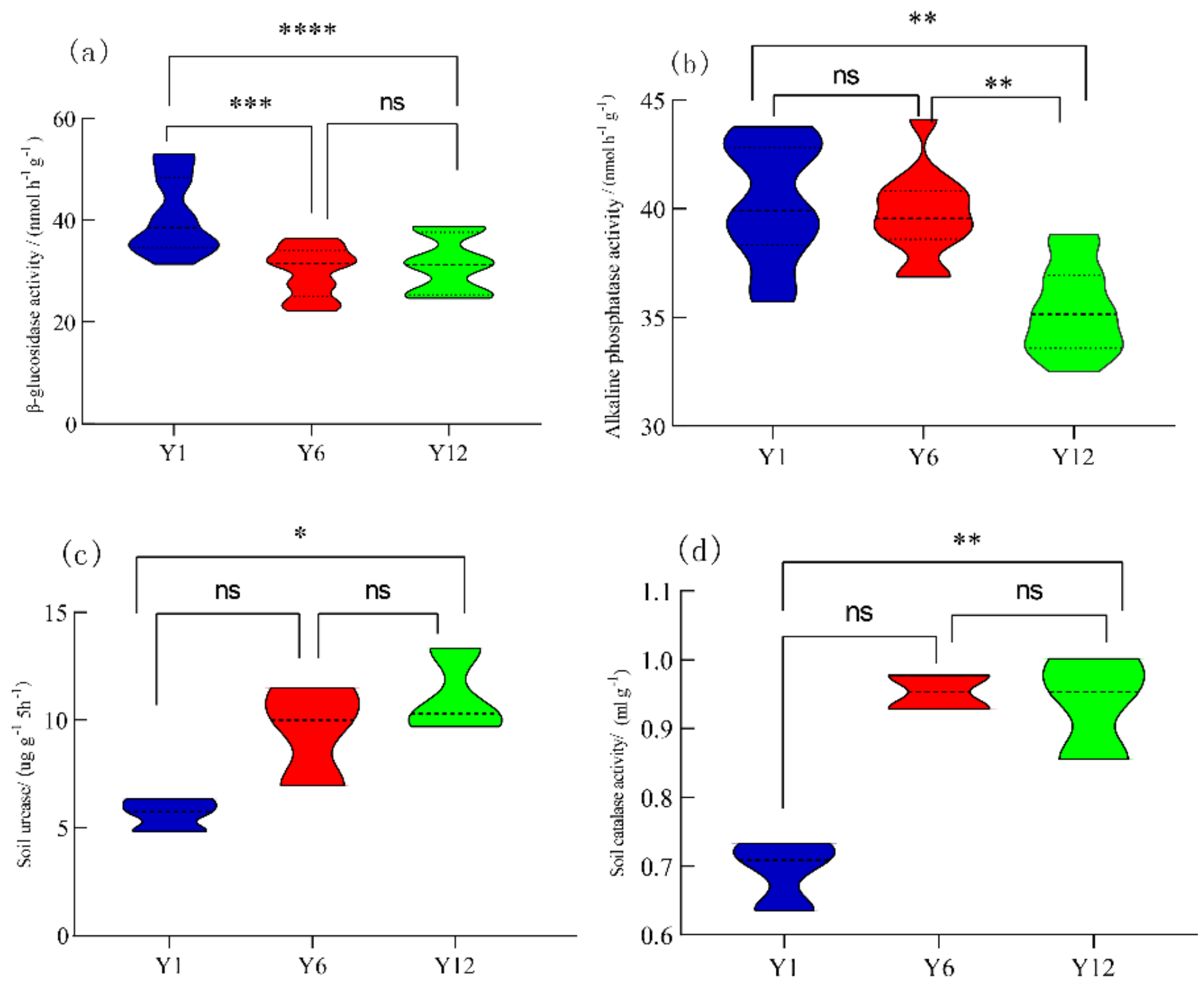

Figure 1

Violin plots showing the variance of soil enzyme activities under different continuous cropping

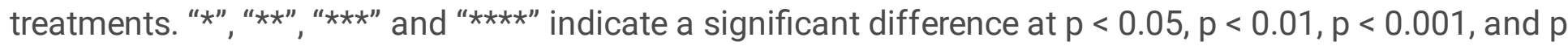
$<0.0001$ between two groups, respectively. Note: $Y 1$, only planting for one years; $Y 6$, continuous cropping for 6 years; Y12, continuous cropping for 12 years, respectively. 
(a)

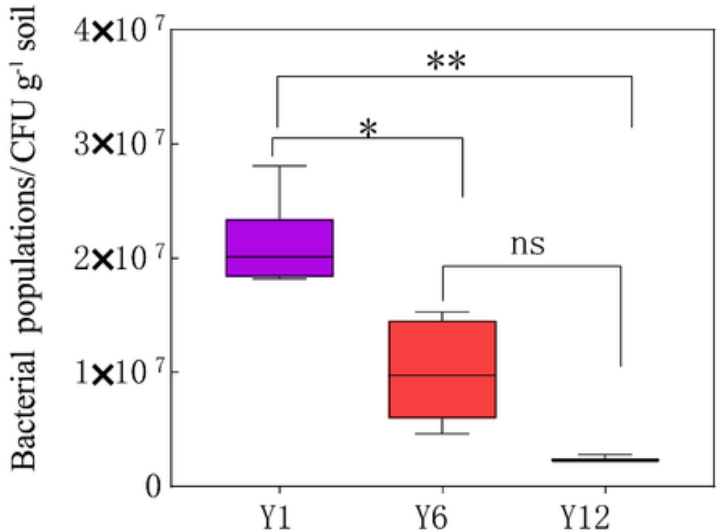

(b)

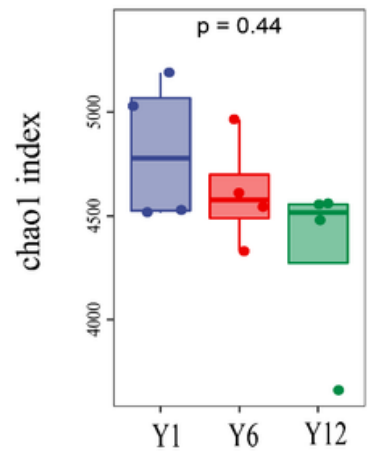

(c)

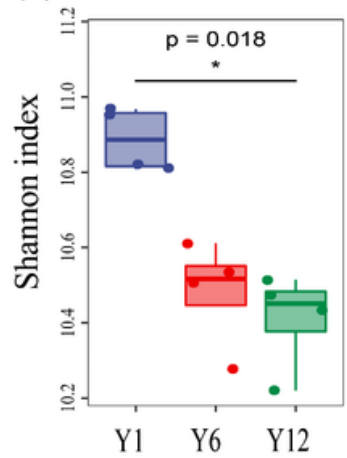

(d)

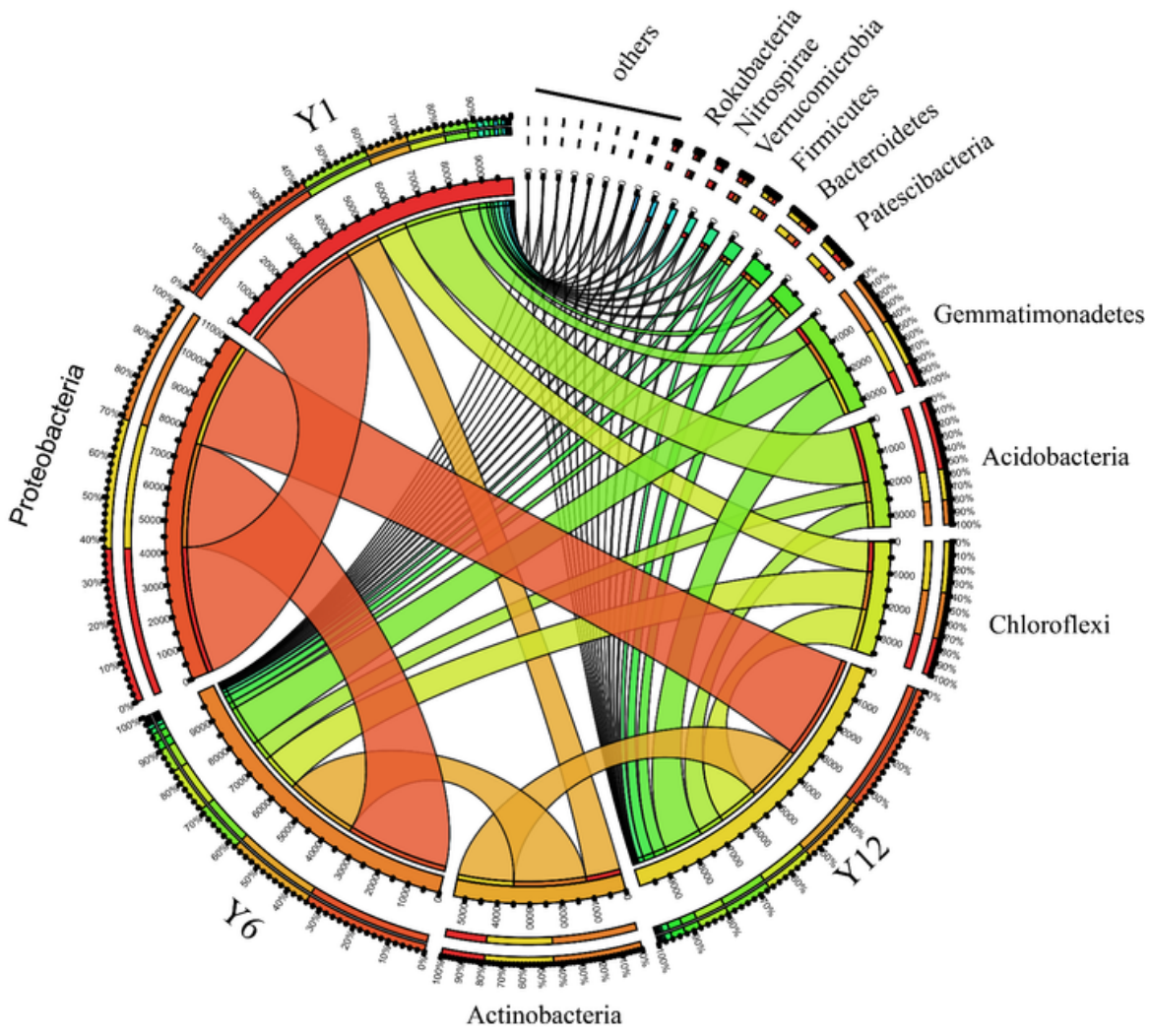

Figure 2

The variances of bacterial populations under different continuous cropping treatments were shown in (a). The variances of the a-diversity of Chao 1 index and Shannon index over continuous cropping years were shown in (b) and (c). Circle Diagram analysis showing the changes of relative abudnace of bacterial phyla level among different continuous cropping treatments. Asterisks above the columns indicate different significant levels ( ${ }^{*} \mathrm{P}<0.05 ;{ }^{\star *} \mathrm{P}<0.01$; ${ }^{* \star} \mathrm{P}<0.001$, and ${ }^{\star \star \star *} \mathrm{P}<0.0001$ ). Note: $\mathrm{Y} 1$, only planting for one years; $Y 6$, continuous cropping for 6 years; $Y 12$, continuous cropping for 12 years, respectively. 
(a)

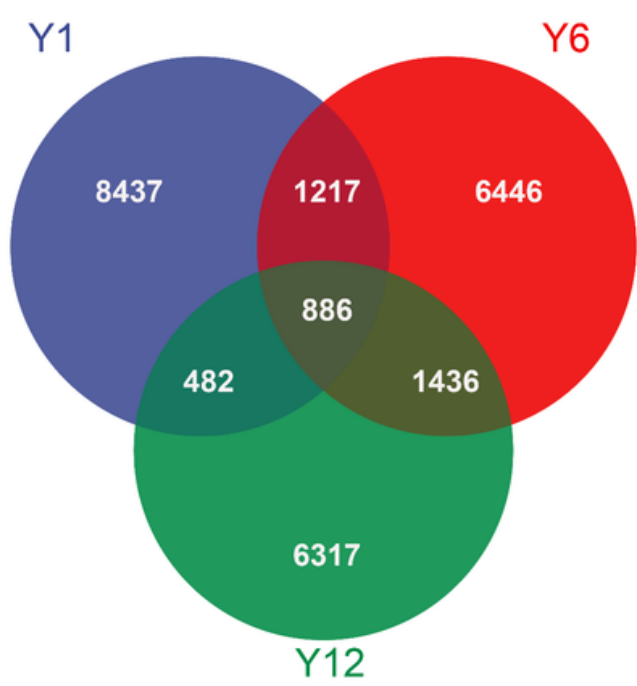

(c)

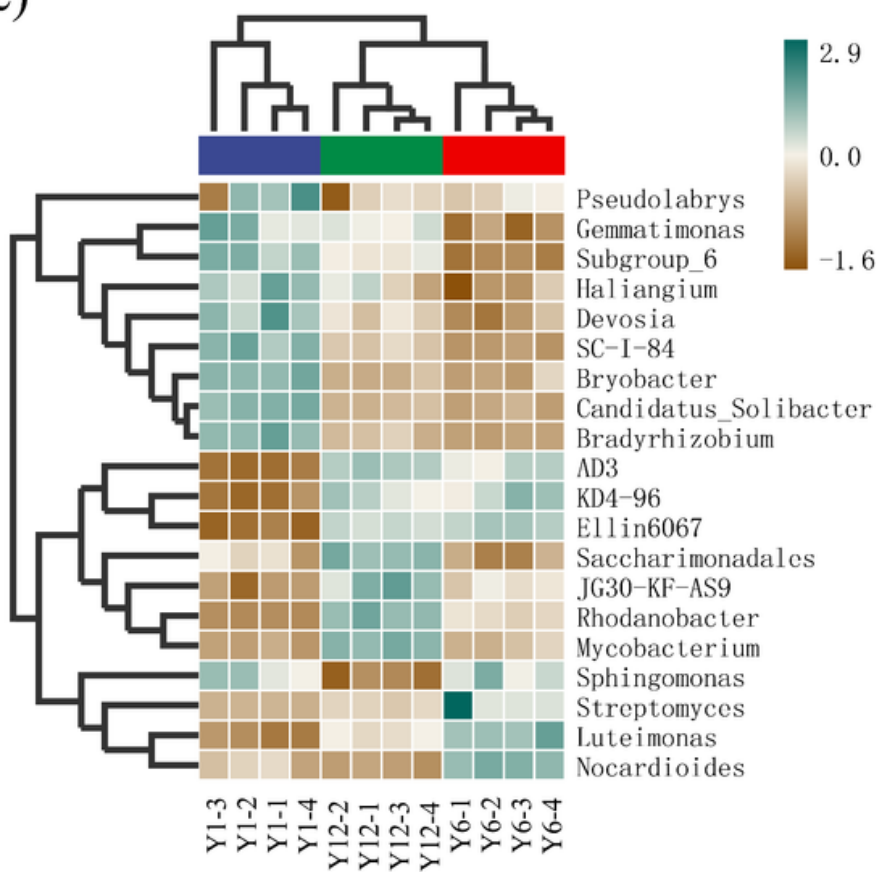

(b)

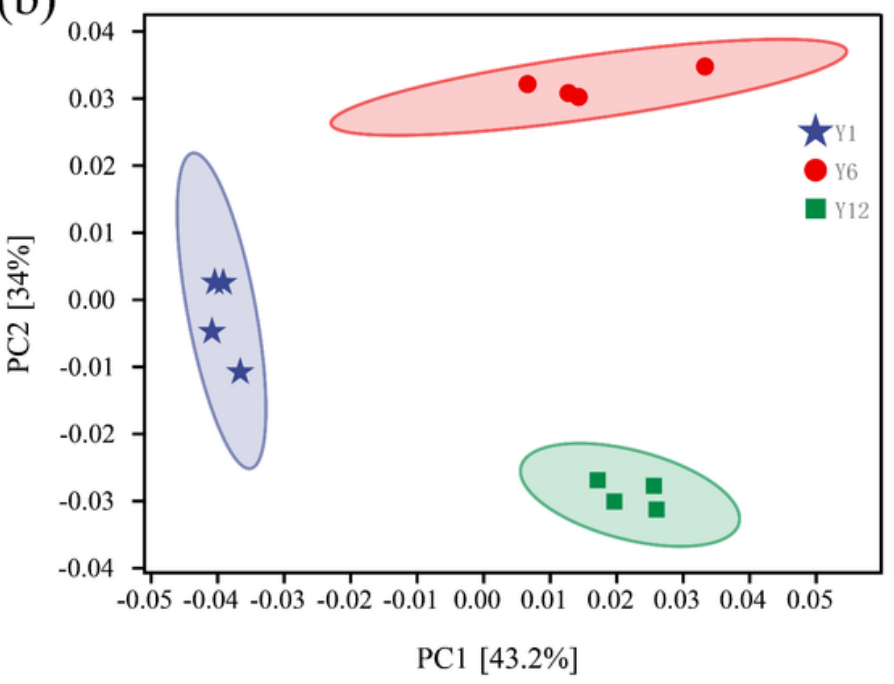

(d)

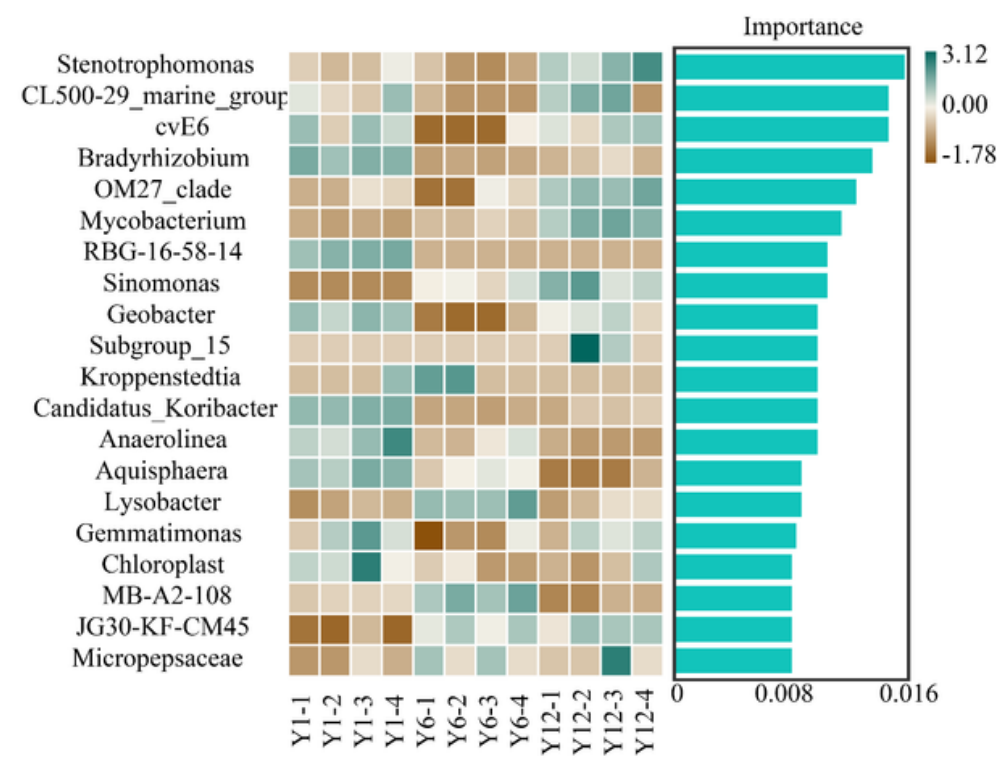

Figure 3

The shared and unique OTUs of $\mathrm{AOB}(\mathrm{A})$ and $\mathrm{AOA}(\mathrm{B})$ communities among different treatments as assessed by Venn diagram (a). The changes of bacterial community compositions as assessed by PCA (b); Heatmap showing the relative abundance of top 20 genera under different continuous cropping treatments (c); Random forest analysis revealing the key genera of bacterial community structure under continuous cropping(d). 
- Proteobacteria Acidobacteria Chloroflexi $\bullet$ Actinobacteria

- Gemmatimonadetes - Nitrospirac - Patescibacteria

- Verrucomicrobia

- Rokubacteria

- Firmicutes

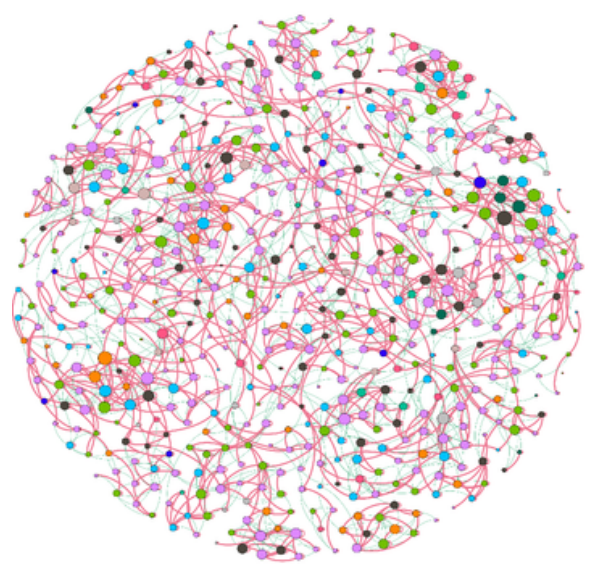

(a)
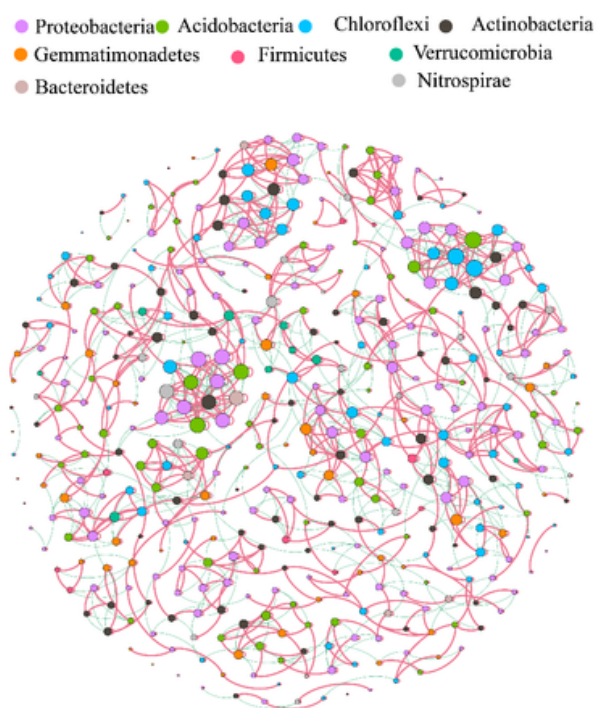

(b)
- Proteobacteria $\bullet$ Acidobacteria $\bullet$ Chloroflexi $\bullet$ Gemmatimonadetes

- Actinobacteria $\bullet$ Bacteroidetes $\bullet$ Patescibacteria $\bullet$ Firmicutes

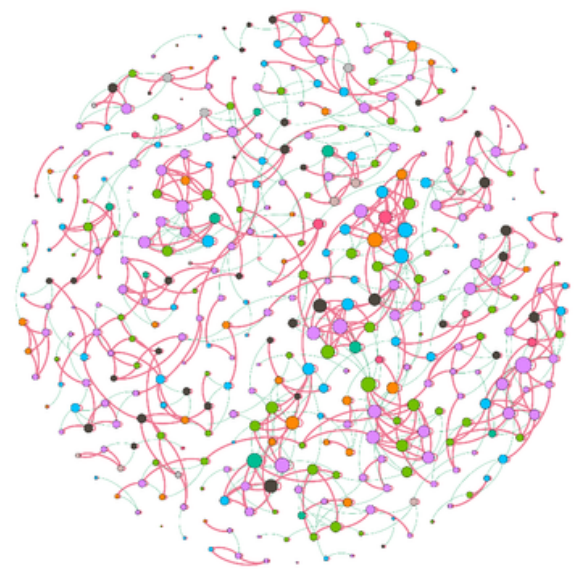

(c)

\begin{tabular}{llll}
\hline \multicolumn{1}{c}{ Topological index } & Y1(a) & Y6(b) & Y12(c) \\
\hline Nodes & 595 & 428 & 381 \\
Edges & 2352 & 1468 & 1096 \\
Average degree & 7.906 & 6.83 & 5.753 \\
Modularity & 29.64 & 12.27 & 4.614 \\
\hline
\end{tabular}

\section{Figure 4}

Properties of soil microbial correlation-based network under different continuous cropping systems. Network analysis showing the intra-associations inter-associations among different bacterial taxa. Networks were constructed at the operational taxonomic unit (OTU) level. The size of each node is proportional to the number of connections (i.e., degree). Edges between nodes indicate significant correlations among nodes (Spearman's $r>0.08$, P-value $<0.01$ ). Red and green edges represent $T$ positive and negative associations between taxa. 


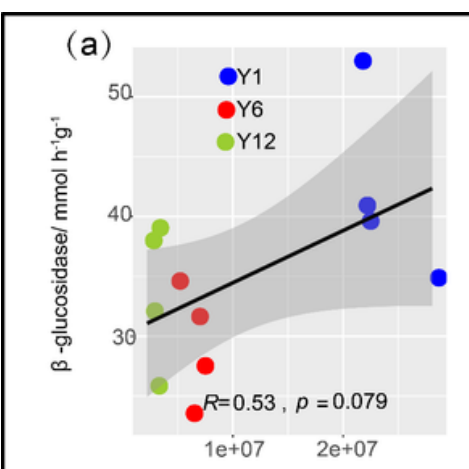

Bacterial populations /CFU g ${ }^{-1}$ soil

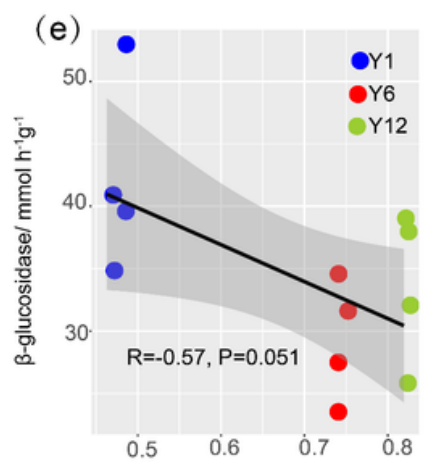

Bacterial compositions /Bray-Curtis

(i)

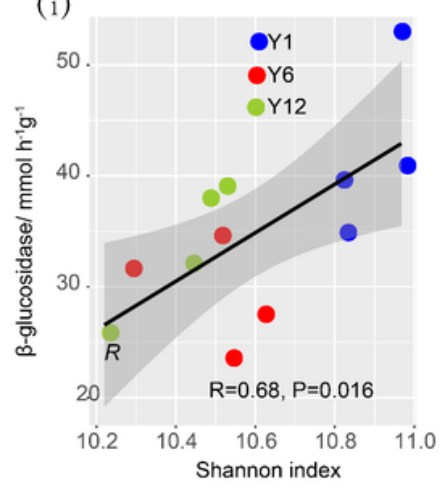

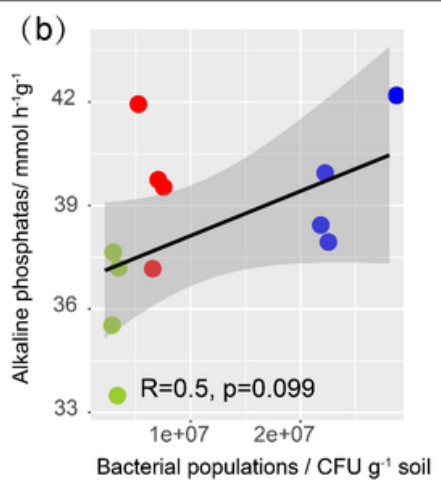

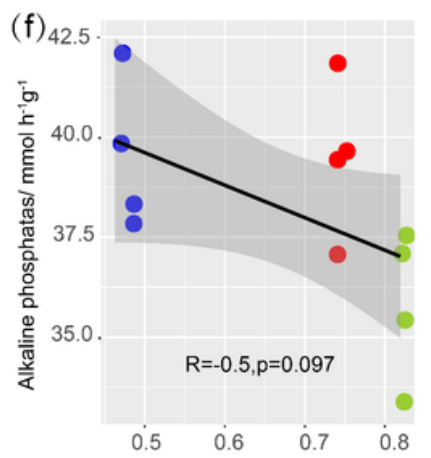

Bacterial compositions/ Bray-Curtis

(j)

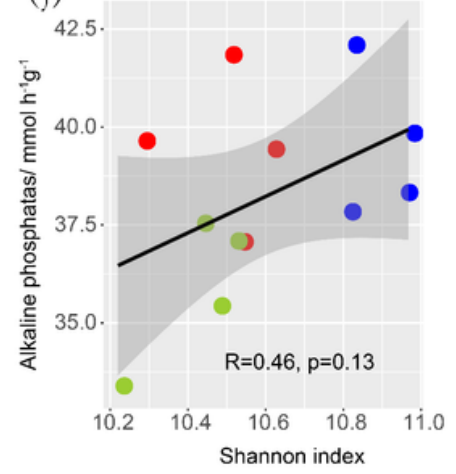

(c)
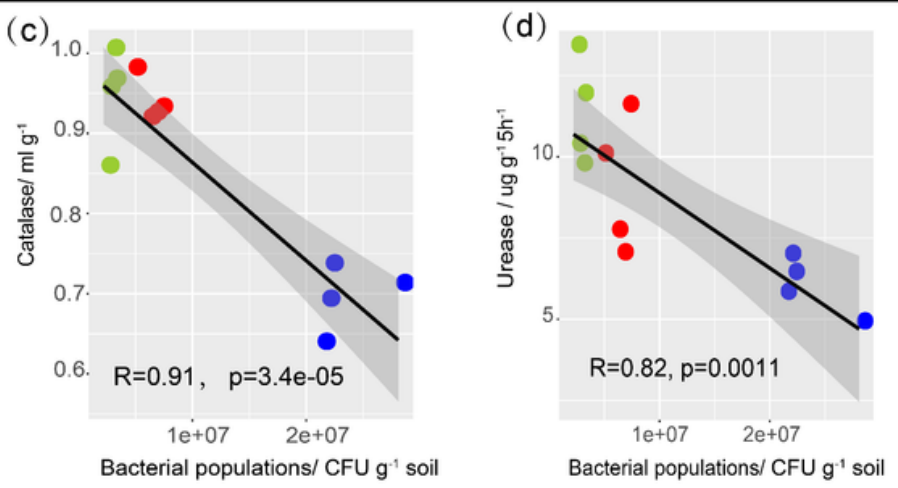

(g)

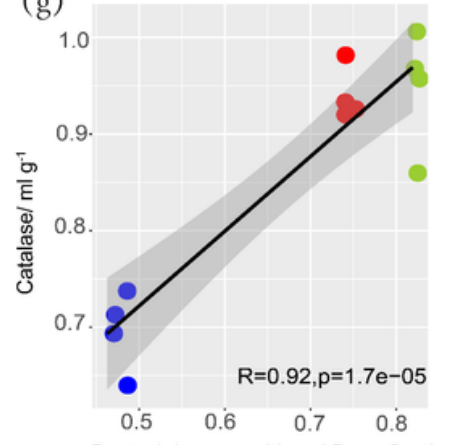

Bacterial compositions/ Bray-Curtis

(k)

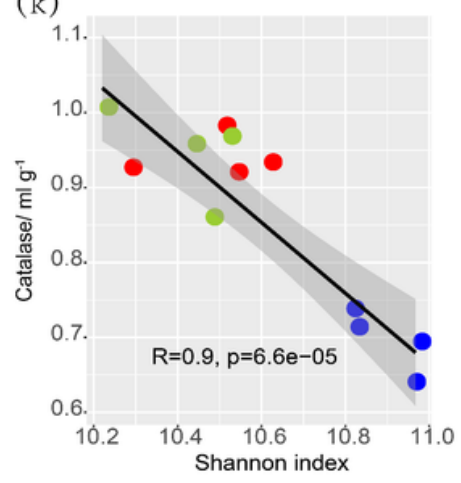

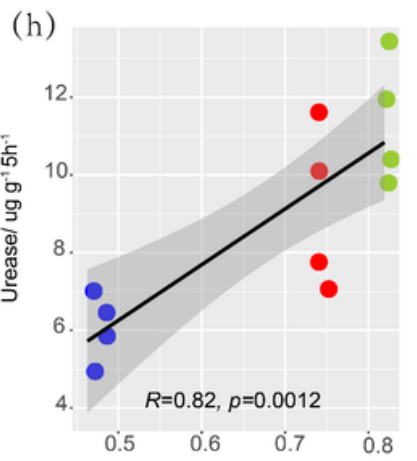

Bacterial compositions/ Bray-Curtis

(1)

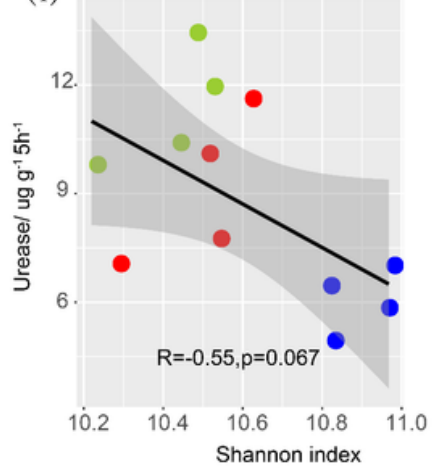

Figure 5

The correlations between soil enzymatic activities and soil bacterial biological indicators. 


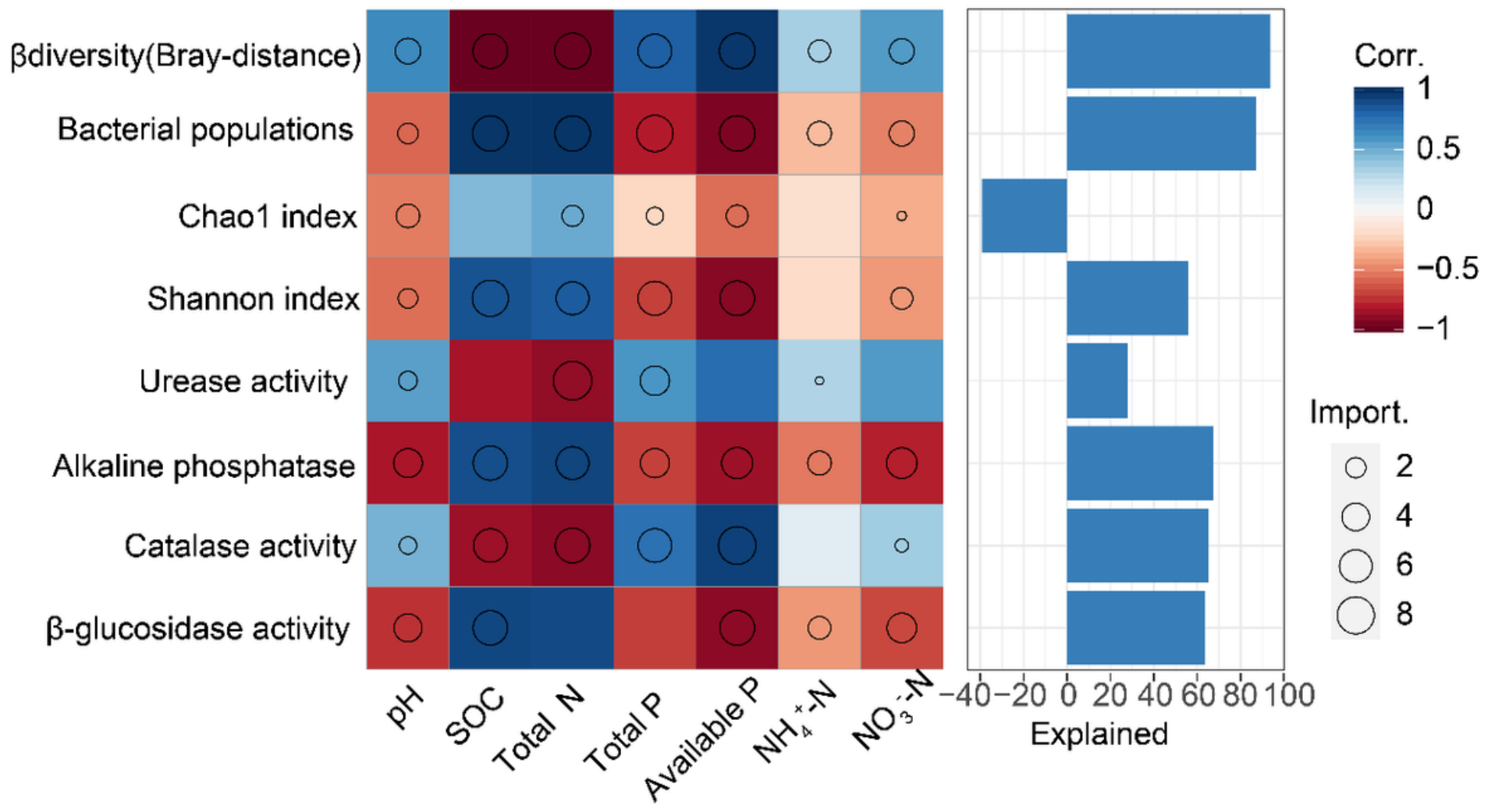

Figure 6

The predictor importance of edaphic factors $(\mathrm{pH}, \mathrm{SOC}, \mathrm{TN}, \mathrm{TP}, \mathrm{AP}, \mathrm{NH} 4+-\mathrm{N}$, and NO3-N) to the enzymatic activities and the populations, composition and diversity of bacteria. 